\title{
THE ECONOMIC CONSEQUENCES OF MR TRUMP
}

\section{Max Corden and Ross Garnaut}

*Corden and Garnaut, Faculty of Business and Economics, University of Melbourne, Victoria 3010. Corresponding author: Garnaut, email ross.garnaut@unimelb.edu.au.

\section{Introduction}

The Trump administration has implemented two major initiatives in economic policy: cutting rates of corporate and personal income tax, leading to an increase in the budget deficit; and increasing (or threatening to increase) barriers against imports. The threats have been greatest against countries with which the United States has large bilateral trade deficits (China, Mexico, and Canada). They have been on the receiving end of the sharpest rhetoric about the need to restrict imports to reduce bilateral trade deficits. These initiatives are meant to increase growth in the United States economy as a whole, and especially to increase employment and incomes of workers employed in manufacturing in rust belt states, which swung towards Trump in the 2016 elections. What will be the effects of these policies? Will they provide benefits to the people that Mr Trump says they are meant to help?

The consequences of Mr Trump's first economic policy initiative--the tax cuts and the larger budget deficit--are primarily macro-economic. This initiative affects broad economic aggregates including average prices, total incomes, total employment, expenditure, trade and current account balances, the exchange rate and interest rates. The consequences of the second--increases or threats of increases in protection--are essentially micro-economic, affecting the allocation of resources across different economic activities.

This is the author manuscript accepted for publication and has undergone full peer review but has not been through the copyediting, typesetting, pagination and proofreading process, which may lead to differences between this version and the Version of Record. Please cite this article as doi: $10.1111 / 1467-8462.12295$ 
2. The tax cuts

\subsection{The Background: Budget Deficit and Monetary Policy}

The effects of an economic policy change depend on the circumstances in which it is implemented. The influence of the context on the outcome is especially strong with macro-economic initiatives, like increasing the budget deficit. However, economic context is also relevant for changes in resource allocation policies, such as an increase in protection. The Trump policy changes came after a long, slow but reasonably steady increase in United States economic activity and employment after expansionary monetary policies were adopted in 2008 and 2009 to offset the effects of the Great Crash of 2008.

The budget deficit had been falling with economic expansion but remained high for the current advanced stage of the business cycle. Public debt as a ratio to GDP continues to grow-and has reached levels unprecedented except in wartime or its immediate aftermath. Easy money after the Great Crash of 2008 has supported a relatively low dollar exchange rate, helping US export industries, but has not removed a persistent trade deficit. The low interest and exchange rates assisted a moderate expansion of manufacturing employment including in the rust belt states from about 2010. This followed more than two decades of decline accumulating to over 40 percent of manufacturing employment from 1988. Unemployment has fallen to historically low levels-levels that economists would usually consider to be full employment.

\subsection{The Tax Cuts and the Budget Deficit}

The complicated Trump tax cuts include an acceleration of the rate of depreciation of business investment, which tends to expand the scale of current business investment relative to other economic activity. It includes temporarily preferential reductions in tax rates for companies bringing back to the United States funds held in offshore tax havens, alongside a change from taxation of global to national income of United States corporations.

Here we put aside the complications and focus on the core of the package: an increase in the budget deficit and increase in public debt to fund lower income tax rates for corporations and individuals. The tax cuts lead to an increase in domestic expenditure. Since there is full employment, the increase in demand will have to be met by an increase in the trade deficit. 
Higher inflation establishes a tendency for market interest rates (that is longer term rates) to rise. The monetary authorities are bound to respond to higher inflation by raising policy (shorter-term) interest rates. In turn, higher interest rates attract capital inflow and place upward pressure on the nominal exchange rate. An appreciation of the real exchange rate-from some combination of increased prices and an increase in the nominal exchange rate--is the proximate cause of the increase in the trade deficit. Thus the end of the process sees a higher level of domestic expenditure, a higher trade deficit and a higher real exchange rate than before the budget policy change. There is a larger trade deficit with the world as a whole and probably a higher bilateral deficit with each major trading partner.

Total employment is the same as before the fiscal expansion, because the starting point is full employment.

The distribution of income is altered by the tax cuts, with owners of capital and business assets better off at the expense of workers with little but their labour to sell. There will also be some tendency for incomes as well as employment to rise for workers in the expanding non-tradables industries; and to fall relatively and perhaps absolutely in the contracting tradables industries. The tradables industries include manufacturing.

Another effect on the distribution of income is intertemporal: people living, working and paying taxes now benefit from the deficit-funded tax cut, and people living later pay the costs.

So if we focus purely on the effects of the tax cuts, the rust belt industrial workers get temporarily higher incomes from the increased expenditure funded by capital inflow, but lose relative to others and perhaps absolutely from the decline in tradables employment, and from the redistribution of income towards owners of capital and business assets brought about by the tax cuts.

\subsection{Later reversal of capital flows. Asymmetric effects}

At some later time, the capital inflow has to be replaced by outflow of funds to provide a return for and to repay the earlier inflow of capital that was induced by the increased budget deficit. This causes the real exchange rate to depreciate, and that raises prices, and lowers living standards. The temporary boost to average living standards is taken away. One asymmetry is that an increase in living standards from the budget expansion goes smoothly, but the subsequent withdrawal of the increase causes pain, is resisted, and generates unemployment and grumpy voters while it is in process. This is an important asymmetry. 
A second asymmetry may result when industrial skills and business institutions lost in the contraction of tradables industries during the temporary expansion are not quickly or easily replaced when the old opportunities are restored by real exchange rate depreciation. Some businesses and tradables production lost in the contraction may be lost forever, and replaced by others that are less remunerative.

A third asymmetry is conceivable. The costs could be high. A debt funded expansion in circumstances of full employment may encourage a speculative boom in asset prices, or a bubble, which develops a life of its own. Eventually the bubble bursts, leading to the sudden reversal not only of the original expansion, but of the speculative element in the increase in asset prices. This may lead to a large loss in economic activity and employment, and a painful process of restoring full employment of the kind experienced following the Great Crash of 2008.

The first stage of these effects from debt-funded tax cuts in circumstances of full employment are already in evidence-some in anticipation of announced changes. US inflation has started to rise. US interest rates are rising - at the short end, from Federal Reserve policy, and at the long end in the market place. The exchange rate of the US dollar is somewhat higher than before the election of $\mathrm{Mr}$ Trump.

\section{Protection Policy: Three Important Issues}

We now come to Trump's protection policies. We cannot be sure what Mr Trump will do in the protection area, and what the effects of his measures will be. But it seems clear that he is unsympathetic to internationally co-operative measures and that he wants - but may not achieve certain outcomes, notably the reduction of US trade deficits with many countries and with the nonUS world as a whole. He has promised that the US will not participate in future regional and multilateral trade liberalisation, and that he will increase restrictions on imports into the US in general and against imports from some countries in particular. Uncertainty surrounding business decisions caused by such a situation raises the supply price of investment into industries involved in international trade, reduces the gains from trade and subdues economic activity in general. Quite apart from the factors to be discussed below this uncertainty itself raises the cost of doing business and, among other things, reduces the benefits of trade. (For completeness, we should acknowledge that the dampening effect of uncertainty about trade policy on business investment may offset to some extent the effects of the tax cut in increasing short term expenditure-without obviating the need to reverse the increase in the budget deficit at some time in the future). 
There are three important issues that are not widely understood but are extremely relevant in the current situation. These three considerations need to be kept in mind as we discuss in detail below some of the aspects and effects of possible Trumpian policies.

\subsection{The Mutual Gains from Trade and the Mutual Cost of Protection}

When China exports manufactures to the US, there are potential gains from trade for both China and the US. Of course, this assumes that countries are rational and exploit their potentialities. China has a comparative advantage in producing diverse manufactures. The US has a comparative advantage in other fields, for example, the production and exporting of aeroplanes, soybeans and information technology, and it is in its interest - and in particular in the interest of its consumers and of people employed or owning assets in its other industries-- to import Chinese manufactures. Thus both the benefits of trade and the cost of protection are mutual.

But this idea goes contrary to the popular view (held strongly by Trump, for example) that only the exporters gain from trade in a particular product. Imports are somehow a loss.

In this example, when the US imposes tariffs on the import of Chinese manufactures, such tariffs being designed to reduce trade, both China and the US lose the gains from trade.

There are some complications that we should note for completeness. Revenue from a tariff which reduces trade will go wholly to the United States in this case, even though both countries will be losers from the reduction of trade. This may bias the costs of the restriction of trade against the exporting country. The opposite result would follow from an export tax that had a similar effect in reducing total gains from trade.

The "cost of protection" is felt by both potential exporters and potential importers. This is the basic and very important argument for free trade and rests on the concept of comparative advantage. If the United States imposes tariffs on imports from China, it hurts not only China but also the United States itself, and if China then reciprocates by imposing an export tax or any measure that has the same effect as a tariff, it also hurts both countries. There are qualifications to this simple argument, having to do with the effect of tariffs and export taxes on prices (the terms of trade), but the basic message remains and is very important. With respect to the existence of mutual trade, countries have common interests. 


\subsection{The Dependence of Trade Balances on Macroeconomic Factors}

We noted when we were discussing the effects of the increase in the budget deficit that trade balances are determined by macroeconomic factors and not on policies which affect the allocation of resources across industries.

Currently the United States has an overall deficit in its current account. This is a deficit relative to all other countries combined, id est the "Rest of the World". The current account refers to all goods and services combined. Combined US imports exceed US exports.

President Trump is very keen to eliminate, or at least reduce this deficit. It seems that he wants to achieve this by separate protectionist policies designed to reduce imports from many countries and thus improving the US current account balance individually with these countries. But there is a problem. For the trade surplus of the "Rest of the World" relative to its trade with the United States to be reduced there have to be appropriate capital account changes.

At present US investments exceed savings, so that the US capital account is in surplus, while the Rest of the World capital account is in deficit. In other words, in the US investment is greater than savings and in the rest of the world combined savings are greater than investment. One element of the low savings of the US is the recent Trump-determined fiscal deficit. Thus macroeconomic policy is in the way of what appears to be a target that he wants to achieve by protectionist - id est microeconomic - policy. But he is unlikely to achieve this target because of macroeconomic prospects.

\subsection{Compensate Losers when Policies or Events yield National Benefits}

While US consumers and residents taken as a whole gain from increases in imports of low-cost goods and services from abroad, people working or owning assets in the import-competing industries may lose.

Consider the following case. China has become a transformed economy which creates the opportunity of mutually beneficial trade between China and others, notably the US. There are clear gains from trade. China exports cheap diverse manufactures, benefiting both US consumers and companies that use Chinese inputs of various kinds. In addition the US benefits from exporting to China various products, aeroplanes, soybeans and information technology for example. There are 
standard gains from trade which raise living standards in both countries. All this is well known and applies not just to the US but to many countries (such as Australia).

But there is a catch. There are also losers from the Chinese boom. Such losers may be in China and in many other countries or regions, but here we focus on some US regions and industries, principally producing manufactures which lose sales as a result of increased imports from China. As we know, this naturally leads to political reactions. There is a natural tendency to advocate, and perhaps impose tariffs on imports from China, and so moderate the adverse regional or sectoral effects. But this will also lose some (or all) of the potential gains from trade, as many consumers and retailers (for example) in the United States would point out.

This kind of issue arose in Western Europe in the latter part of the $19^{\text {th }}$ century when the US boom in wheat exports had adverse effects on European farmers. This led to European protection of agriculture, and is the origin of protectionism that has lasted for many years. The better solution is to combine free trade policies, designed to allow benefits from the gains from trade, with social policies. Such social policies would be financed by taxes on the gainers in the community, and then use the benefits to assist the losers to adjust or be compensated. This should have been done in recent years in the United States. A social welfare policy as practised in various ways in Australia and some European countries should thus complement a free trade policy. It is not necessary to lose the benefits of free trade in order to avoid some people losing from increased trade. (This recommendation also applies to the consequences of technological and other advances, which are beneficial in their effect for many, but also do create losers).

\subsection{The Trump Measures. Gainers and Loser}

The increase in US tariffs on steel and aluminium will cause production of those products in the US to increase. Their imports will fall and employment in the US in this field will increase, which is indeed the purpose of this measure. But there will be losers. Costs and prices of goods (and services) containing steel and aluminium will tend to rise in the US and production and employment in these industries may fall. And lower imports of some goods is associated with a rise in the exchange rate that increases imports of other products. Once the adjustment has been completed, average incomes in the US will be a bit lower than before, employment in steel and aluminium a bit higher and in other tradables industries a bit lower. The overall trade balance will remain more or less the same as it was before and total unemployment will be unaffected.

The big question is: do the gains for steel and aluminium workers at the expense of others increase total American welfare? If those who gain from increased trade do not compensate those who lose, the answer depends on whether you value the welfare of steel and aluminium industries much more 
highly than the welfare of a much larger number of other Americans. But those who gain can afford to pay higher taxes to compensate the losers, and still be better off. So we can unequivocally say that total American welfare is increased by the combination of free trade and appropriate compensation policies.

The fact that there are losers indicates that such protection may not survive pressures from interest groups. For this reason, some of the increases in protection proposed by $\mathrm{Mr}$ Trump may not actually be implemented.

It is hard to find an advantage for any group of Americans for the Trump policy of focussing on bilateral trade deficits rather than the overall position. Restriction on imports of steel or aluminium from one country but not others will change the source of imports but not the amount-except in the unlikely event that the rearrangement of international supply arrangements raises the overall cost of imports by a significant amount. Reducing a trade deficit with one country will simply increase deficits with others, without materially affecting the total. The normal workings of the international economy cause a single country to have deficits with some countries and surpluses with others, with the sum of global balances averaging out to zero.

The increase in US protection, unlike the tax cuts discussed above, is unlikely to affect its overall trade balance. Does that matter? Is the overall trade and current account position a matter for concern at all? These are macro-economic and not resource allocation questions. In general, a trade surplus in one country and deficit in another reflects differences in preferences related to allocating income between savings and investment. A surplus reflects a tendency for people in a country to value savings more than domestic investment at prevailing interest rates. A deficit in another country reflects a tendency for people to value investment more than savings. That one country runs a trade deficit and another a surplus may reflect differences between the countries in demography, time preferences, or stages of development reflected in differences in opportunities for domestic investment.

Free international movement of capital allows the different preferences of countries to be reflected in economic decisions and outcomes. The Chinese, Japanese and German preferences to save more than they invest at home in current circumstances allows Mr Trump to give rein to his preference for Americans to spend more than they earn, and to invest more than they save. Free movement of capital allows American as well as Chinese, Japanese and German preferences to be fulfilled. Be that as it may, increased protection in America in current circumstances will not reduce American overall trade deficits.

\subsection{Other Countries' Reactions to US Protection}

This article is protected by copyright. All rights reserved 
Partner countries' gains from trade will be adversely affected by an increase in American protection. Which will lose more-the US or partner countries? Generally trade restriction damages the smaller country proportionately more than the larger country. For the purposes of assessing the effects of an increase in American protection, the rest of the world as a whole is the other country. It is much larger than the US, and is damaged proportionately less-and the damage is divided among many countries. Thus the US is the main loser from an increase in US protection, but other countries lose as well.

Several international reactions to the increase in US protection are possible. Foreign Governments may choose not to react. They may choose to reduce their own trade barriers, either to persuade $\mathrm{Mr}$ Trump that he should now desist from his own increases in protection, or to increase gains from trade to offset losses from the change in US policy. They may retaliate by raising their own trade barriers, in the hope of forcing a reversal of American policy-or simply to persuade domestic political constituencies that they are "standing up" to American pressure.

The best response by other countries to the change in US policy from the point of view of economic welfare in partner countries, and obviously for welfare in the US and the world as a whole is to reduce their own protection. If this is done, they will offset-perhaps more than offset-the losses from the increase in US protection. If their reactions persuade Mr Trump to desist, so much the better.

Doing nothing is second to partner countries reducing their own protection. At least the costs of $\mathrm{Mr}$ Trump will not be compounded by reduced gains from trade as a result of one's own policy decisions.

The very worst outcome for the partner countries, the US and the world as a whole is retaliation that leads to an actual increase in protection. This compounds the loss of gains from trade resulting from the American action -in the retaliating countries, and in the US and the world as a whole as well.

A recent authoritative study of the history of trade policy in the US throws light on the costs of one egregious policy intervention in the United States-the Smoot Hawley increase in tariffs in 1931 (Irwin, 2017). Irwin shows that the large increases in the US tariff in 1931 had negative effects on world economic activity. International retaliation had larger negative effects. But the largest effects of all were the way that US policy undermined domestic political support for open trade in other countries, opening the way to more general increases in protection in many places 


\section{Conclusion}

We have shown that the Trump tax cuts and increase in budget deficits will temporarily raise average incomes for Americans in general. However, the fiscal expansion will be reversed sooner or later-and the costs of reversal may exceed the benefits of the current intervention. The trade policy interventions will lower incomes for Americans in general with the costs possibly increased by other countries' retaliation.

Workers in the steel and aluminium and other "rust belt" industries, -the group that the Trump policies are said to be designed to help-- will share in the temporary national gain from the budget policies, and in the national losses from the increase in protection. Their share of national income will be increased by protection, but reduced by the budget interventions. Overall it is not impossible that they will experience a small gain in the near term-although it is possible that they could lose, as the distributional effects of the budget interventions, including through the appreciation of the real exchange rate, may be large.

The US trade deficit is certain to increase as a combined result of the two policy interventions. As we have shown, it will increase as a result of the increase in the budget deficit and real exchange rate, and it will not be reduced by the increase in protection and associated dollar appreciation. That will surprise Mr Trump, as he does not seem to be aware of the consequences described in this paper. It may make him angry. If that leads to another round of increases in protection, the consequences of Mr Trump will increase.

\section{Reference}

Irwin, Douglas (2017), Clashing Over Commerce: A History of US Trade Policy, University of Chicago, Chicago. 


\section{University Library}

\section{- M M N E R VA A gateway to Melbourne's research publications}

Minerva Access is the Institutional Repository of The University of Melbourne

Author/s:

Corden, M;Garnaut, R

Title:

The Economic Consequences of Mr Trump

Date:

2018-09-01

Citation:

Corden, M. \& Garnaut, R. (2018). The Economic Consequences of Mr Trump. AUSTRALIAN ECONOMIC REVIEW, 51 (3), pp.411-417. https://doi.org/10.1111/1467-8462.12295.

Persistent Link:

http://hdl.handle.net/11343/284425 